made up from 'minor' as well as 'major' courses. On paper, a minor course would take half the time of a major course. Theoretically, a student could choose between a concentrated pattern of studies of the kind now conmon and a much broader and more liberal education. The Schools Council is obviously keen on the concept, though it is bound to be a long time before the universities and the schools are thoroughly convinced. In the hope of showing that its proposals are practical, the Schools Council is working hard to design teaching time-tables in which major and minor courses are intertwined. In time, no doubt, there will be practical experiments in schools. Success could bring a new pattern of sixthform science teaching within a decade. Certainly the talk that there is bound to be of this proposal will sharpen discussion of the four-year university course.

\section{Essays on Humanity}

IN his Two Essays on Humanity, K. W. Monsarrat is concerned first with "Man's Thoughts" and then with "Man's Health" (Pp. 19. Liverpool: Henry Young and Sons, 1965). In his first essay he elaborates the thesis that the most precious of all man's neural abilities is the ability to form validity judgments and to exert his powers accordingly. He emphasizes the need for recognition that the word 'mind' represents an abstract idea of the individual's thought-producing activity by that part of his cell-structure which the microscopist terms his braincortex, and refers to the clinical evidence that changes in the blood content as the blood-stream passes through glandular structures may affect the production of thought. In the second essay, he criticizes the development and organization of the health service, arguing that a really comprehensive scheme has been prevented by the party structure of Parliament assisted by the short-sightedness of the British Medical Association, which, like Parliament itself, twice failed to grasp the opportunity, originally presented by the report of the Dawson Committee in 1920. In consequence, he maintains that the family doctor has been forced to choose between reducing the standard of his care of his patients, submitting to financial straits which mean relative poverty, abandoning his profession or emigrating.

\section{British Acoustical Society}

Tнe Acoustics Groups of tho Institute of Physics and the Physical Society and the Society of Acoustic Technology in the United Kingdom have spawned a new socioty - the British Acoustical Society-which is intended to cover the "rapid growth of interest and discovery in the various branches of acoustics in Britain". The now society hopes to bring some simplification to a field of study in which a number of separate societies and sub. groups have sprung up in recent years. It will be concerned with "all aspects of sound, hoaring and vibration", and will be engaged in problems of great public interest such as aircraft and traffic noise, the design of concert halls and the industrial uses of sound, including ultrasonics. The planning of the new society has been done by a committee undor Sir Gordon Sutherland as chairman, and the now society will be managed provisionally by a council with Dr. A. J. King as ohairman and Prof. E. J. Richards as vice-chairman. Thero is to be an inaugural meeting during May 5-6 at the Department of Physics of the Imperial College of Science and Technology, London, S.W.7. Further information can be obtained from Dr. R. W. B. Stephens at that address.

\section{Chemistry and Metabolism of Lactic Acids}

Chemistry and Metabolism of $\mathrm{L}$ - and $\mathrm{D}$-Lactic Acids contains a series of papers prosonted at a conference held in November 1964 (Ann. N.Y. Acad. Sci., 119, Article 3. By N. R. Alpert and 45 other authors. Pp. 851-1165.
New York: New York Academy of Sciences, 1965. 6 dollars). The objects of the conference, as stated by the co-chairmen, were to demonstrate the need to use specific isomers in metabolic studies rather than the D,L-mixtures frequently used, and to bring together present knowledge on lactic acid. The first of these objectives is worthwhile, since investigations with stereospecific enzymes have shown that the information gained by using racemic substrates is often misloading, and many of the papers in this volume amply show that a great deal more informa. tion can be obtained using the individual isomers of lactic acid. The large amounts of information available on some aspects of the subject make the second objective difficult to attain: the material available on the lactic dehydrogenases could in itself fill a volume. The volume opens with a paper on the chemistry of lactic acid, followed by a series of papers dealing with specific enzymes concerned in the metabolism of the lactic ceid isomers and other hydroxy acids. The study of the metabolism of the lactic isomers then proceeds from these specific enzymes to metabolic pathways in micro-organisms, tissue preparations, isolated organs and the intact animal. The final section of the volume consists of papers on the medical aspects of lactic acid metabolism. This section contains a paper on the metabolism of the lactic acid isomers in human brain in both normal and mental patients, followed by four papers on lactic acid levels in the blood during acidosis, shock, neonatal life and hyperventilation. The volume represents a useful survey of the various aspects of lactic acid chemistry and metabolism, in which condensation of the subject-matter due to space limitations is largely offset by lists of references at the end of each paper. As such it can be recommended to anyone interested in the important aspects of this field, and also to anyone tempted to use racemic mixtures in enzymatic or metabolic investigations.

\section{Occurrence of Rana ridibunda in a Hot Spring near Edremit (Turkey)}

Atilla Özalpan, of the Department of General Zoology, University of Istanbul, has written to the Editor as follows: "It is unusual to find vertebrate species in hot springs. For this reason, we have found it worth-while to report the occurrence of Rana ridibunda in a hot spring near Edremit (Balikesir, Turkey). The temperatures of different parts of the hot spring are shown in Fig. 1.

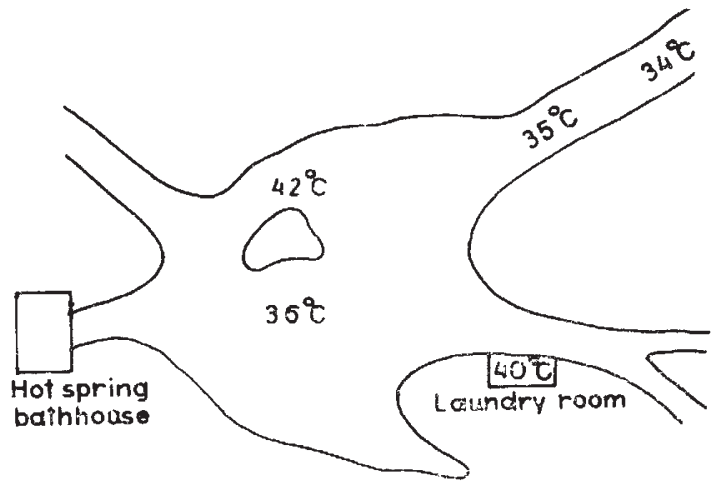

Fig. 1. The hot spring (Derman) ncar Edremit

"On April 23, 1965, many small metamorphosed individuals and tadpoles of different sizes were collected from the hot spring. The larvae and the frogs appeared to have no particular preference for a special temperature in the hot spring. They were found in its coldest and hottest regions. It seems that the frogs are adapted not only to the tomperature of the water but also to its salinity. The physiological basis of this phenomenon is being worked out in our laboratory and will be published olsowhere." 